Western New England University School of Law Digital Commons@Western New England University School of Law

2014

\title{
Amicus Brief of Labor Relations and Research Center, U. Mass., Amherst in Browning-Ferris, NLRB RC-109684
}

Harris Freeman

Western New England University School of Law, hfreeman@law.wne.edu

George Gonos

State University of New York at Potsdam

Follow this and additional works at: http://digitalcommons.law.wne.edu/facschol

Part of the Labor and Employment Law Commons

\section{Recommended Citation}

Harris Freeman and George Gonos, Amicus Brief of Labor Relations and Research Center, U. Mass., Amherst, in Browning-Ferris, NLRB RC-109684 (June 26, 2014).

This Article is brought to you for free and open access by the Faculty Publications at Digital Commons @ Western New England University School of Law. It has been accepted for inclusion in Faculty Scholarship by an authorized administrator of Digital Commons @ Western New England University

School of Law. For more information, please contact pnewcombe@law.wne.edu. 
UNITED STATES OF AMERICA

BEFORE THE NATIONAL LABOR RELATIONS BOARD

X

BROWNING-FERRIS INDUSTRIES

OF CALIFORNIA, INC., D/B/A BFI NEWBY

ISLAND RECYCLERY

and

Employer

FPR-II, LLC, D/B/A LEADPOINT

BUSINESS SERVICES

Employer

Case 32-RC-109684

and

SANITARY TRUCK DRIVERS AND

HELPERS LOCAL 350,

INTERNATIONAL BROTHERHOOD OF

TEAMSTERS

Petitioner

X

BRIEF OF AMICUS CURIAE

LABOR RELATIONS AND RESEARCH CENTER, UNIVERSITY OF MASSACHUSETTS, AMHERST

IN SUPPORT OF PETITIONER

SANITARY DRIVERS AND HELPERS LOCAL 350, INTERNATIONAL BROTHERHOOD OF TEAMSTERS

Professor Harris Freeman

Western New England University School of Law

1215 Wilbraham Road

Springfield, MA 01119

413-221-3746

Harris.Freeman@law.wne.edu

Professor George Gonos

State University of New York

Department of Sociology

Potsdam, NY 13676

786-803-8360

gonosgc@potsdam.edu 


\section{TABLE OF CONTENTS}

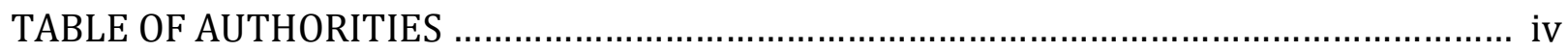

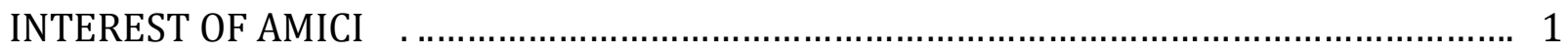

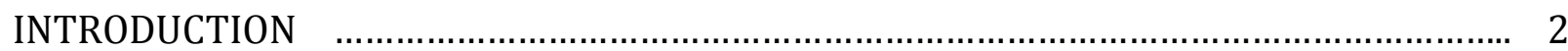

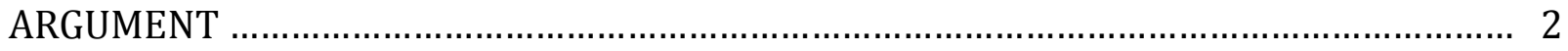

I. THE TEMPORARY STAFFING INDUSTRY'S LABOR-ONLY CONTRACTING MODEL HAS CREATED A PRECARIOUS AND HIGHLY VULNERABLE SECOND-CLASS WORKFORCE …...............................................................

II. THE TEMPORARY STAFFING INDUSTRY AND ITS WORKFORCE ARE A GROWING, INTEGRAL COMPONENT OF LABOR MARKETS IN THE MANUFACTURING, LOGISTICS AND SERVICE SECTOR

A. Temporary staffing work has continued its rapid expansion In the decade since the NLRB decided Oakwood Care

B. Large concentrations of permatemps are routinely deployed to perform core business functions at user firm facilities

C. The problems facing the temporary workforce have become more acute and widespread since 2004

III. TEMPORARY STAFFING ARRANGEMENTS TYPICALLY CREATE TERMS AND CONDITIONS OF EMPLOYMENT THAT ARE CO-DETERMINED BY SUPPLIERS AND USER BUSINESS ENTITIES

IV. APPLICATION OF THE JOINT-EMPLOYER STANDARD TO BARGAINING UNIT DETERMINATIONS INVOLVING THE TEMPORARY STAFFING INDUSTRY REQUIRES THE BOARD TO BE COGNIZANT OF THE DISTINCT FEATURES OF LABOR-ONLY CONTRACTING

A. Joint employment typically arises where large concentrations of long-term agency workers routinely carry out a user firm's core business functions in a single location

B. The BFI/LBS temporary labor services agreement as written and implemented establishes co-determined and shared terms and conditions of employment

C. Wages, hours of work and health and safety conditions are co-determined and shared by BFI and LBS 
V. WAGES, HOURS AND CONDITIONS OF WORK CANNOT BE EFFECTIVELY BARGAINED WITHOUT HAVING THE SUPPLIER AND USER OF THE TEMPORARY WORKFORCE AT THE BARGAINING TABLE 


\section{TABLE OF AUTHORITIES}

$\underline{\text { Cases }}$

Arrez v Kelly Services, Inc., 522 F. Supp.2d 997 (N.D. Ill. 2007).......................................... 11,12

Boire v. Greyhound, 376 U.S. 473 (1964) ……......................................................................... passim

NLRB v. Browning-Ferris Industries of Pa., Inc. 691 F.2d 1117 (3 ${ }^{\text {rd }}$ Cir. 1982) .......... 3, 13, 24

Carillo v. Schneider Logistics, Inc., No. 11-08557 (C.D. Cal. 2011) ...................................... 11, 21

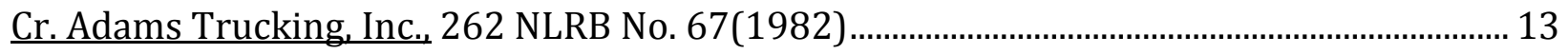

G. Heilman Brewing Co., Inc. v. NLRB, 879 F.2d 1526 (7th Cir. 1989) .................................. 25, 29

Greyhound Corp. and Floors, Inc., 153 NLRB 1488 (1965), ,............................................. passim

Laerco Transportation, 269 NLRB 324 (1984), ....................................................................... passim

Manpower Inc. of Shelby Cty., 164 NLRB No. 137 (1967)........................................................ 19

NLRB v. Greyhound Corp. 368 F.2d 778, 780 (5 $5^{\text {th }}$ Cir. 1966)................................................... 13

NLRB v. Kentucky River Community Care, Inc., 532 U.S. 706.................................................. 29

NLRB V. Weingarten, 420 U.S. 251, 266 (1975) ................................................................... 14, 28

NLRB v. Western Temporary Services, 821 F.2d 1258 (7th Cir. 1987) ........................... 25, 276

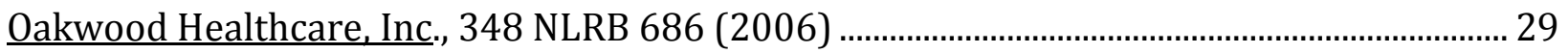

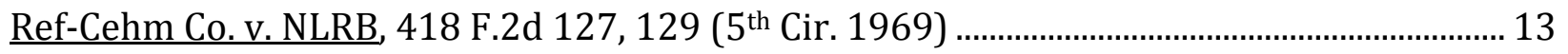

Sun-Maid Growers and IBEW Local 100, 239 NLRB 346 (1978)............................................... 22

TLI, Inc., 271 NLRB 798 (1984), ......................................................................................... passim

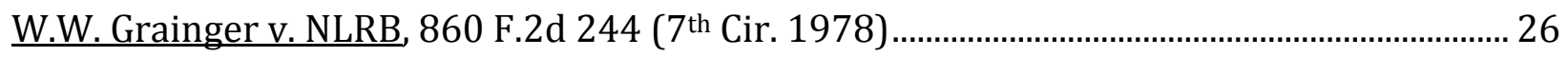

Zheng v Liberty Apparel Co, 355 F.3d 61 (2d Cir. 2003) .............................................................. 12

\section{$\underline{\text { Statutes }}$}

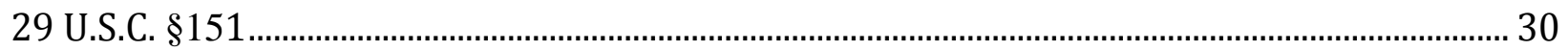

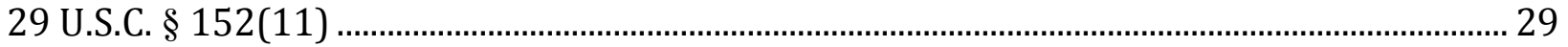




\section{Regulatory Agency Memos}

Injury and Illness Recordkeeping Requirements, TWI Bulletin No 1., OSHA, https://www. osha. gov /temp_workers/ OSHA_TWI_Bulletin.pdf

Protecting the Safety and Health of Temporary Workers, OSHA, April 29, 2013, https://www.osha.gov/pls/oshaweb /owadisp.show_document? p_table= INTERPRETATIONS\&p_id=28613;

$\underline{\text { Other Authorities }}$

Books

Stephen R. Barley and Gideon Kunda, Gurus, Hired Guns, and Warm Bodies: Itinerant Workers in a Knowledge Economy (2004).

Erin Hatton, The Temp Economy: From Kelly Girls to Permatemps in Postwar America, (2011). 18,19

Heidi Gottfried, Learning the Score: The Duality of Control and Everyday Resistance in the Temporary-Help Service Industry, in J.M. Jermier, et al., eds., Resistance and Power in Organizations, 102-127 (Routledge 1994).

Edward A. Lenz and Dawn R. Greco, Co-Employment: Employer Liability Issues in ThirdParty Staffing Arrangements (American Staffing Association $4^{\text {th }}$ Ed. 2007). 16,17

Robert E. Parker, Flesh Peddlers and Warm Bodies: The Temporary Help Industry and its Workers, (1994) 18,19

Jackie Krass Rogers, Temps: The Many Faces of the Changing Workplace (ILR Press 2000)

David Weil, The Fissured Workplace: Why Work Became So Bad For So Many and What Can Be Done to Improve It (Harvard Univ. Press 2014)

Journals \& Reports

Bad Jobs in Goods Movement: Warehouse Work in Will County, Illinois, Warehouse Workers for Justice and Center for Urban Economic Development, Univ. of Ill., Chicago, http://www.warehouseworker.org/badjobsgoodsmovement.pdf. 8 
Peter Cappelli, and J.R. Keller, A Study of the Extent and Potential Causes of Alternative Employment Arrangements, 66 Ind. \& Lab. Rel. Rev. 874 (2013)

Juan D. De Lara, Warehouse Work: Path to Middle Class or Road to Economic Insecurity, USC Program for Environmental \& Regional Equity, (Sept. 2013), https:// dornsifecms.usc.edu/assets/sites/242/docs/WarehouseWorkerPay_3_web.pdf 8

Janet Druker and Celia Stanworth, Partnerships, Human Resource Mgt. J. at pincite; see James Peck and Nik Theodore, The Business of Contingent Work, 12 Work, Employment \& Society 655 (1998)

Druker and Stanworth, Partnerships and the Private Recruitment Industry, 11 Human Resource Mgt. J. 73 (2001).

Isabel Fernandez-Mateo, Who Pays the Price of Brokerage? Transferring Constraint through Price Setting in the Staffing Sector 72 Amer. Sociological Rev. 291 (2007).....

Harris Freeman and Gonos, Taming the Employment Sharks: the Case for Regulating For-Profit Labor Market Intermediaries in High Mobility Labor Markets, 13 Employee Rts. \& Empl. Policy J. 285 (2009) .. $5,10,13$

Freeman and Gonos, The Challenge of Temporary Work in the Twenty-first Century: Flexibility with Fairness for the Low-Wage Temporary Workforce, A Working Paper on the Future of Work in Massachusetts, Labor Relations and Research Center, U. Mass., Amherst (2011), http://digitalcommons. law. wne.edu/facschol/160/ .......................... 11

George Gonos, The Contest Over 'Employer' Status in the Postwar United States: The Case of Temporary Help Firms, 31 Law \& Society Review 81 (1997) 16

Gonos, Fee Splitting Revisited: Concealing Surplus Value in the Temporary Employment Relationship, 29 Politics \& Society 589 (2001)

Heidi Gottfried, Mechanisms of Control in the Temporary Help Service Industry, 6 Sociological Forum 699 (1991).

Arne Kalleberg, Nonstandard Employment Relations: Part-time, Temporary and Contract Work, 26 Annual Review of Sociology 341 (2000); 16

Torstein Nesheim \& Ruth Rørvik. Exploring Dilemmas in the Relation Between Temporary Help Agencies and Customer Firms, 42 Personnel Review 67 (2013). 16,19

Catherine Ruckelshaus, et al., Who's the Boss? Restoring Accountability for Labor Standards in Outsourced Work (NELP May 2014), www.nelp.org..

Nik Theodore, Political Economies of Day Labour: Regulation and Restructuring of Chicago's Contingent Labour Markets, 40 Urban Studies 9 (2003). 7 
M. Vidal and L. M. Tigges, Temporary Employment and Strategic Staffing in the Manufacturing Sector, 48 Industrial Relations 55 (2009).

Joshua Wright, Temp Work and the Slow Return of Manufacturing, Economic Modeling Specialists, Int'l. (April 8, 2014), http://www.economicmodeling.com /2014 /04/08/temp-workers-and-the-slow-return-of-manufacturing

Wright, Temp Employment is Dominating Job Growth in the Largest Cities, International Modeling Specialists, Int'l. (June 2013), http:// www.economicmodeling.com/ 2013/06/21/temp-employment-is-dominating-job-growth-in-the-largest-cities-is-thata-good-thing/.

News Articles

David Bacon, Invisible No More: Threatened with deportation and paid illegally low wages, East Bay recycling workers did the unthinkable: They fought back, San Francisco Bay Guardian Online (June 10, 2014), http://www.sfbg.com/2014/06/10/invisible-nomore

BLS News, U.S. General Accounting Office (Feb. 2005), http:// www.bls.gov/news.release /conemp.nr0.htm

Michael Grabell, The Expendables: How the Temps Who Power the Corporate Giants and Getting Crushed, ProPublica, (June 27, 2013), http://www.propublica.org/article/ theexpendables-how-the-temps-who-power-corporate-giants-are-getting-crushe ....... passim

Michael Grabell, Olga Pierce \& Jeff Larson, Temporary Work, Lasting Harm, ProPublica (Dec. 18, 2013) http://www. propublica.org/article/temporary-work-lasting-harm ..... 11

Laura Newberry, Temp Jobs Become Way to Go for Many Employers, The Indianapolis Star (August 16, 2013) available at http://www. usatoday.com/ story/money/business /2013/08/16/economy-temporary-workers/2665645/.

Lydia DePIllis, This is What a Job in the U.S.'s New Manufacturing Industry Looks Like, The Washington Post (March 9, 2014), http://www.washingtonpost.com/blogs/wonkblog /wp /2014/03/09/this-is-what-a-job-in-the-u-s-new-manufacturing-industry-looks-like

Ronald A. Wirtz, Matchmaker, Matchmaker, Fedgazette: Newspaper of Federal Reserve Bank of Minnesota (Jan. 2014), http://www.minneapolisfed.org/publications_papers /pub_display. $\mathrm{cfm}$ ?id=5256. 
Other Information

A Manager's Guide to Understanding Co-Employment, Kelly Services (1995) 17

Elite Staffing Case Study, http://www.elite staffinginc.com/waste-services-case-study.php 9

Johnson\& Johnson/Kelly Services Contract Highlights (January 1995)..................................... 27

Leadpoint Business Services Home Page, http://www.leadpointusa.com/................................ 9

Kelly Services, Managing Co-Employment Risk When Using a Staffing Agency (February 07, 2009)

Microsoft Overhauls Permatemp Compensation, Washington Alliance of Technology Workers/WashTech $($ Oct 26, 1998), www. washtech.org/roundup/ billrate.html

Staffing Employment Grew 4\% in 2013: New Data From Quarterly ASA Staffing Employment and Sales Survey (March 6, 2014). 


\section{INTEREST OF AMICI CURIAE}

The University of Massachusetts Labor Relations and Research Center (Center), founded in 1964, as an integrated program of graduate education, research, and direct service to workers and the labor movement. A primary concern addressed by the Labor Center's research and educational missions is the decline of collective bargaining and the rise of inequality that has accompanied the rapid growth of precarious forms of nonstandard and contingent employment. To this end, the Center initiated a Future of Work Project in 2004 to provide labor and government policy-makers with fact-driven research that examines the growth of the low-wage, contingent labor force as well as the economic and technological forces that are driving this development.

The Labor Center, along with labor centers at other University of Massachusetts campuses, has funded research and published a series of books and reports on the future of work. ${ }^{1}$ The Center also sponsored numerous conferences attended by hundreds of labor advocates and government officials where these issues were discussed and debated. The Future of Work Project complements two other of the Center's research areas. A LaborCommunity Research Project explores how unions and community-based groups can mobilize in partnership to address labor market shifts, plant-closings, subcontracting, with particular emphasis on how these problems impact low-wage workers, persons of color, women and immigrants. The Center has also developed a strategic corporate research program allows unions and their allies to efficiently access and analyze comprehensive

The authors of this brief have co-wrote a report published by the Future of Work Project, as well as other legal and sociological research cited herein, addressing the role of the temporary staffing industry. They have also both taught courses on the legal and sociological issues posed by the use of temporary staffing arrangements and have consulted extensively with worker centers and other organizations involved in defending the workplace rights of the temporary staffing industry workforce. 
corporate business data to facilitate their responses the shifting terrain in which labor union organizing and collective bargaining are taking place.

\section{INTRODUCTION}

Non-standard employment is compromising the ability of American workers to exercise their right to self-organization and collective bargaining. In response to the Board's request, this amicus brief provides an up-to-date assessment of the temporary staffing industry as it relates to the ability of temporary staffing workers to exercise fundamental rights guaranteed to them by federal labor law. It is widely recognized that the ubiquitous presence of millions of temporary staffing industry workers in all sectors of the U.S. labor market has given rise to a second-tier workforce, with lower wages and fewer benefits than the standard employees performing exactly the same work in the same commercial enterprise. The Board's current joint-employer test, as applied in this case, is a barrier to temporary staffing workers exercising their right to self-organization and collective bargaining. Without the ability to bargain with both the user and supplier firms that employ them, temporary workers will find it virtually impossible to alter their second-class terms and conditions of employment at the bargaining table.

\section{$\underline{\text { ARGUMENT }}$}

The assessment of the temporary staffing industry presented herein is provided to support the Petitioner, Teamsters Local 350 and to urge that the Board find that BrownFerris Industries (hereinafter BFI or user employer) is a joint employer of the temporary staffing workforce it has retained to carry out the core recycling operations at its Republic Services facility. This conclusion is warranted because the unit employees' terms and conditions of employment are co-determined and shared by BFI and LBS pursuant to the 
BFI/LBS Staffing Agreement, the socio-economic structure of the work arrangement, and the intertwined role of the BFI and LBS supervisory personnel.

In this context, the Board's application of its joint-employer doctrine should be informed by and tailored to the current economic realities and labor market role of the temporary staffing industry. To this end, the Board should revive the traditional standard for determining joint-employer eschewed in Bush-era Board rulings and reject the jointemployer test as it was applied in TLI, Inc., 271 NLRB 798 (1984), enfd. 772 F.2d 894 (3d Cir. 1985), and Laerco Transportation, 269 NLRB 324 (1984), as both of these rulings fail to give adequate consideration to the unique economic realities of labor-only contracting. Applying the TLI/Laerco interpretation of the joint-employer doctrine in this case, or in any case involving the temporary staffing industry, is at odds with principles set forth in Boire v. Greyhound, 376 U.S. 473 (1964) and NLRB v. Browning-Ferris Industries of Pa., Inc. 691 F.2d 1117 (3rd Cir. 1982). Continuing to apply the crabbed approach to jointemployer status in $\underline{\mathrm{TLI}}$ and Laerco will have the practical effect of depriving the burgeoning temporary staffing workforce of the ability to exercise their right to engage in collective bargaining with both employers who jointly control and share the terms and conditions of their employment.

I. THE TEMPORARY STAFFING INDUSTRY'S LABOR-ONLY CONTRACTING MODEL HAS CREATED A PRECARIOUS AND HIGHLY VULNERABLE SECOND-CLASS WORKFORCE

Employment through the temporary staffing industry is, by definition, precarious. There are no explicit or implicit promises of ongoing employment in temporary staffing arrangements and, most often, the benefits and expectations attendant to long-term standard employment relationships are non-existent. Only 8 percent of temporary help 
workers receive health insurance from the staffing agency and just 9 percent receive pension benefits compared to 53 percent of workers in traditional jobs. ${ }^{2}$ Fringe benefits commonly offered to standard employees, e.g., paid vacations, life insurance, and sick days, are routinely denied to temp workers. Temp worker wages are on average 25 percent below standard employees performing the same work. ${ }^{3}$ Compared to the standard workforce, temps tend to be younger, less educated ${ }^{4}$ and disproportionately comprised of minority workers. ${ }^{5}$ For unskilled, low-wage temps, like the recycling workers at BFI's facility, all indices of precariousness and vulnerability increase exponentially, particularly when immigrant status becomes a factor. ${ }^{6}$

The structural hallmark of the temporary industry's labor-only contracting model, triangular employment, is a form of subcontracting that inherently blurs the lines of

2 BLS News, U.S. General Accounting Office (Feb. 2005), http:// www.bls.gov/news.release /conemp.nr0.htm

${ }^{3}$ See Michael Grabell, The Expendables: How the Temps Who Power the Corporate Giants and Getting Crushed, ProPublica, (June 27, 2013), http://www.propublica.org/article/ theexpendables-how-the-temps-who-power-corporate-giants-are-getting-crushe

${ }^{4}$ Among the temporary workforce as a whole, $17 \%$ of temp agency workers had less than a high school diploma, compared to $9 \%$ of workers in traditional arrangements.. And workers between 16 and 24 years of age, temps are more than twice as likely to have dropped out of high school than those in traditional arrangements. See BLS News, U.S. General Accounting Office (Feb. 2005), http:// www.bls.gov/news.release/conemp.nr0.htm

${ }^{5}$ Almost half of the temporary staffing agency workforce is either Black (22.7 percent), Asian (5.2 percent) or Hispanic (21 percent). Id.

${ }^{6}$ Although statistical data is not available, all other evidence indicates that the low-wage temporary workforce includes large numbers of immigrants and undocumented workers whose vulnerabilities are exacerbated by language and literacy barriers as well as legal status. See e.g. David Bacon, Invisible No More: Threatened with deportation and paid illegally low wages, East Bay recycling workers did the unthinkable: They fought back, San Francisco Bay Guardian Online (June 10, 2014), http://www.sfbg.com/2014/06/10/invisible-no-more 
employer responsibility. ${ }^{7}$ Consequently, the temporary staffing industry has presented long-term, intractable challenges when it comes to enforcing federal and state labor and employment laws. ${ }^{8}$ As a result, the temporary workforce has always been highly vulnerable to all manner of workplace ills, most notably, wage theft, workplace illnesses and accidents, and discrimination. ${ }^{9}$

\section{THE TEMPORARY STAFFING INDUSTRY AND ITS WORKFORCE ARE A GROWING, INTEGRAL COMPONENT OF LABOR MARKETS IN THE MANUFACTURING, LOGISTICS AND SERVICE SECTORS}

The temporary staffing industry workforce is increasingly a significant factor shaping workplace policies and employment practices of major commercial enterprises throughout key sectors of the U.S. economy. This trend, first recognized by the Board in M.B. Sturgis/Jeffboat, 331 NLRB 1298 (2000), served as a foundation for its holding that, under extant Board precedent, temporary staffing agencies and user firms are joint employers of the supplied temp workers.

The importance and permanence of this new labor market reality was stressed by dissenting Board members Liebman and Walsh when Oakwood Care, 343 NLRB 659 (2004), reversed the M.B. Sturgis decision. The dissenters explained that the proper application of the joint-employment test requires the Board keep in mind that the rapidly expanding use of temp agency workers and other non-standard employment relationships was a consequence of massive, competitive pressures of globalization that "appear unlikely

\footnotetext{
${ }^{7}$ Harris Freeman and George Gonos, Taming the Employment Sharks: the Case for Regulating ForProfit Labor Market Intermediaries in High Mobility Labor Markets, 13 Employee Rts. \& Empl. Policy J. 285, 302-306.

${ }^{8}$ Id. at $295-303,331-347$.

${ }^{9}$ See, e.g., id. Freeman and Gonos, The Challenge of Temporary Work in the Twenty-first Century: Flexibility with Fairness for the Low-Wage Temporary Workforce, 9-28, A Working Paper on the Future of Work in Massachusetts (2011), ttp://digitalcommons.law.wne.edu/facschol/160/
} 
to go away." Oakwood Care, 343 NLRB at 664 (Dissent)(quoting Peter Capelli, et al., Change at Work (1997)). Rather, what should be expected is an "increased use of contingent labor as part of [many businesses ]strategic decisions to pursue a low-wage, low-skill, highturnover path to profit making." Id. Members Liebman and Walsh concluded their assessment of the mainstreaming of non-standard work stating that "however real the competitive pressures on American firms, their need to respond to economic uncertainty should not be permitted to erode their employee's right to union representation." Id.

A. Temporary Staffing Work Has Continued Its Rapid Expansion In The Decade Since The NLRB Decided Oakwood Care.

The latest research suggests a more significant role for temp agencies in the twentyfirst century U.S. economy than previously thought. ${ }^{10}$ At the turn of the twenty-first century, 43 percent of all establishments used temp agencies and, among these firms, temp workers made up an average of $8.7 \%$ of their workforce. ${ }^{11}$ The growth of temporary staffing industry employment has climbed rapidly in the aftermath of the Great Recession of 2008. From 2009-2013, the employment services sector, in which temporary staffing firms dominate, accounted for more than 17 percent of net employment gains nationwide. ${ }^{12}$ In some major urban centers, as much as a third of job growth can be

\footnotetext{
10 Peter Cappelli, and J.R. Keller, $\underline{\text { A Study of the Extent and Potential Causes of Alternative }}$ Employment Arrangements, 66 Ind. \& Lab. Rel. Rev. 874, 882-883 (2013) (using for the first time the 2000/2001 National Employer Survey conducted by the U.S. Census Bureau).

${ }^{11} \underline{\mathrm{Id}}$. at 884. (These figures would be even higher if they included other kinds of "off-roll" workers, as Cappelli and Keller call them, i.e., workers employed by Professional Employment Organizations (PEOs) and employee leasing firms that do not differ essentially from temp agencies).

12 Ronald A. Wirtz, Matchmaker, Matchmaker, Fedgazette: Newspaper of Federal Reserve Bank of Minnesota (Jan. 2014), http://www.minneapolisfed.org/publications_papers/pub_display. cfm?id=5256.
} 
credited to the temp sector. ${ }^{13}$ By 2013, U.S. temp and staffing companies employed an average of 3.0 million temporary and contract workers each week, up 4 percent from 2012.14 Because of the churning and high turnover in this labor force, over 12 million individual workers, approximately 10 percent of the entire workforce, cycled through temporary staffing agencies in $2013 . .^{15}$

Temp agency workers are now part of all economic sectors and every occupational group. ${ }^{16}$ This is most dramatic in blue collar and manual labor sectors, where the expansion of temping has outpaced its growth in all other sectors. ${ }^{17}$ In warehousing, for instance, low-wage temp agency workers comprise as much as 36 percent of the workforce as a whole. ${ }^{18}$ In manufacturing and material handling, depending on the skill level required, temporary workers comprise between 16 and 29 percent of the workforce ${ }^{19}$

13 See Joshua Wright, Temp Employment is Dominating Job Growth in the Largest Cities, International Modeling Specialists, Int'l. (June 2013), http:// www.economicmodeling.com/ 2013/06/21/temp-employment-is-dominating-job-growth-in-the-largest-cities-is-that-a-goodthing/(employment gain attributable to temping as 65 percent in Cincinnati; 51 percent in Milwaukee; more than 40 percent in Chicago and Philadelphia).

14 Staffing Employment Grew 4\% in 2013: New Data From Quarterly ASA Staffing Employment and Sales Survey, March 6, 2014.

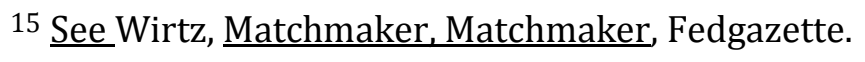

$16 \underline{\text { Id. }}$

17 Joshua Wright, Temp Work and the Slow Return of Manufacturing, Economic Modeling Specialists, Int'l. (April 8, 2014), http://www.economicmodeling.com /2014/04/08/tempworkers-and-the-slow-return-of-manufacturing/; Matthew Dey, et al., Manufacturers' Outsourcing to Staffing Services, 65 Indus \& Lab. Rel Rev. 533 (2012).

18 Nik Theodore, Political Economies of Day Labour: Regulation and Restructuring of Chicago's Contingent Labour Markets, 40 Urban Studies 9 (2003).

19 Grabell, The Expendables, ProPublica (June 27, 2013) 
B. Large concentrations of permatemps are routinely deployed to perform core business functions at user firm facilities

High-volume permatemping has mushroomed since Oakwood Care was decided in 2004. The implications of this widespread phenomenon are now patent for bargaining unit determinations in key industries, such as the logistics and warehousing sector, the recycling industry and basic manufacturing, where large concentrations of permatemps carry out core business functions indefinitely, often staffing entire facilities, job clusters or occupational titles. ${ }^{20}$

Warehousing: Permatemping is the staffing norm at warehouses and distribution centers in the major supply-chain hubs of metro Chicago, northern New Jersey and Southern California that route the lion's share of retail goods to America's shopping malls and big box retailers. In Chicago, temps comprise 67 percent of the warehouse workforce. ${ }^{21}$ In southern California, where WalMart has eleven distribution centers, as many as one-third of the 30,000 temps in Riverside and San Bernardino counties are deployed to warehouse and distribution centers. ${ }^{22}$ The nation's largest on-line retailer, Amazon, reported that 3500 of the 4500 employees it would be hiring at its Chattanooga,

20 See M. Vidal and L. M. Tigges, Temporary Employment and Strategic Staffing in the Manufacturing Sector, 48 Industrial Relations 55 (2009).

${ }^{21}$ Bad Jobs in Goods Movement: Warehouse Work in Will County, Illinois, Warehouse Workers for Justice and Center for Urban Economic Development, Univ. of Ill., Chicago, (survey of 150 warehouse workers in Will County, Ill.) http://www.warehouseworker.org/ badjobsgoodsmovement.pdf (last visited June 24, 2014).

22 Juan D. De Lara, Warehouse Work: Path to Middle Class or Road to Economic Insecurity USC Program for Environmental \& Regional Equity, p. 4 (Sept. 2013), https://dornsifecms. usc.edu/assets/sites/242/docs/WarehouseWorkerPay_3_web.pdf. 
Tennessee distribution center would be temporary staffing agency workers and seasonally employed. ${ }^{23}$

Recycling and Waste Management: As evidenced by this case, permatemping is integral to the recycling and waste disposal industry business model. BFI employs LBS permatemps to staff its entire sorting/assembly line operation. Indeed, LBS and a small group of other staffing agencies occupy a distinct niche, specializing in providing unskilled temp labor for the recycling industry. ${ }^{24}$ Elite Staffing reports that its network of 2000 staffing agencies provides $90 \%$ of the workforce for one of its clients, the "largest provider of waste and environmental services in North America [...] with a national network comprised of thousands of collections operators, transfer stations, active landfill disposal sites, waste-to-energy plants, and recycling plants." 25

Manufacturing: The U.S. manufacturing sector is also dependent on large-scale permatemping. Currently, in major urban areas with high concentrations of manufacturing jobs, the lion's share of new jobs have been in temporary positions. ${ }^{26}$ Temp work now provides 83\% of new jobs in Fresno, California, and Winston-Salem, North Carolina. In York-Hanover, Pennsylvania, which has one of the nation's highest concentrations of manufacturing jobs, 70 percent of new jobs were temporary staffing positions. ${ }^{27}$ In

${ }^{23} \underline{I d}$.

${ }^{24}$ Leadpoint Business Services Home Page, http://www.leadpointusa.com/

${ }^{25}$ http://www.elite staffinginc.com/waste-services-case-study.php (last visited June 24, 2014)

${ }^{26}$ Joshua Wright, Temp Work and the Slow Return of Manufacturing, Economic Modeling Specialists, Int'l. (April 8, 2014), http://www.economicmodeling.com /2014/04/08/tempworkers-and-the-slow-return-of-manufacturing/.

27 Id. 
Indiana, several staffing firms report that manufacturing position account for 60 percent or more of temps jobs. ${ }^{28}$ Permatemping is also endemic in the south, now a major center for auto manufacturing, warehousing and a locus of major labor organizing efforts. ${ }^{29}$ Permatemps are integral to Nissan's assembly facility in Smyrna, Tennessee and paid about half of what standard assembly workers receive. ${ }^{30}$ In South Carolina, 6.7 percent of all jobs are provided through temp agencies and 31.5 percent of these temp jobs fill core manufacturing positions, i.e., assemblers, machinists, packaging operators. At BMW's South Carolina assembly plant, one in twelve workers was a temp in 2012, almost doubling the rate a decade ago. ${ }^{31}$

C. The problems facing the temporary workforce have become more acute and widespread since Oakwood Care was decided in 2004

Long-term under-regulation of temporary staffing industry on the state and federal levels, coupled with lax enforcement of existing laws, has caused the growing temp workforce to suffer from the structural inequities inherent in labor-only contracting and to experience high levels exploitation at the hands of unscrupulous staffing agencies. ${ }^{32}$ This is most pronounced in the low-wage sectors of the economy, where permatemping is now

${ }^{28}$ Laura Newberry, Temp Jobs Become Way to Go for Many Employers, The Indianapolis Star (August 16, 2013) available at http://www. usatoday.com/ story/money/business /2013/08/16/economy-temporary-workers/2665645/.

${ }^{29}$ Grabell, The Expendables, ProPublica (citing BLS data indicating that the number of temporary staffing workers in this area increased from 51,867 in 2009 to 80,990 in 2012).

${ }^{30}$ Lydia DePIllis, This is What a Job in the U.S.'s New Manufacturing Industry Looks Like, The Washington Post (March 9, 2014), http://www.washingtonpost.com/blogs/wonkblog/wp /2014/03/09/this-is-what-a-job-in-the-u-s-new-manufacturing-industry-looks-like/.

31 Grabell, The Expendables, ProPublica

32 Freeman \& Gonos, Taming the Employment Sharks, 13 Employee Rts \& Empl. Policy J. at 290304. 
prevalent. The use of high-volume temping by large and small businesses, particularly in the low-wage sector, is now associated with high levels of wage theft, health and safety violations, and difficulties receiving worker's compensation and unemployment benefits to which they are entitled. ${ }^{33}$

These conditions are due, at least in part, to fissuring of the modern workplace and the blurred lines of authority in triangulated employment arrangements. ${ }^{34}$ In response, successful class-action suits and settlements under the FLSA, in Chicago, California and Massachusetts, ${ }^{35}$ have recovered millions of dollars for permatemps working in warehousing and manufacturing. There is also an epidemic of health and safety violations involving permatemps. ${ }^{36}$ In response, OSHA launched a Temporary Worker Initiative (TWI) ${ }^{37}$ to better protect and identify the health and safety problems facing temp workers,

33 Catherine Ruckelshaus, et al., Who's the Boss? Restoring Accountability for Labor Standards in Outsourced Work, 15-16, 18-21 (NELP May 2014), www.nelp.org.

34 David Weil, The Fissured Workplace: Why Work Became So Bad For So Many and What Can Be Done to Improve It, 159-183, 201-203 (Harvard Univ. Press 2014).

35 See Carrillo v. Schneider Logistics, Inc., No. 11-08557 (C.D. Cal. 2011); Arrez v Kelly Services, Inc., 522 F. Supp.2d 997 (N.D. Ill. 2007); Freeman \& Gonos, The Challenge of Temporary Work in the Twenty-First Century at 13-24, (describing coordinated effort in Massachusetts of legal advocates, workers centers and a health and safety watchdog coalition that uncovered wage and hour violations experienced by temps working in fish processing, rock quarries, light manufacturing and food processing). The state's Misclassification Task Force and the state Attorney General's office have also partnered to step up enforcement of wage and hour law in the low-wage temp sector. Id.

36 Michael Grabell, Olga Pierce \& Jeff Larson, Temporary Work, Lasting Harm, ProPublica (Dec. 18, 2013) http://www. propublica.org/article/temporary-work-lasting-harm. Basing their conclusions on an analysis of millions of workers' compensation claims, these journalists concluded that in five states, representing more than a fifth of the U.S. population, temps face a significantly greater risk of getting injured on the job than permanent employees.

37 See Injury and Illness Recordkeeping Requirements, TWI Bulletin No 1., OSHA, https://www. osha. gov /temp_workers/ OSHA_TWI_Bulletin.pdf. 
whom the agency identifies as a "vulnerable population." ${ }^{38}$ OSHA's TWI came on the heels of a series of OSH citations to correct flagrant safety violations involving temp workers and due to a "series of reports of temporary workers suffering fatal injuries during the first days on the job [and the high] number of temporary workers." 39

Notably, both OSHA and the U.S. Department of Labor have respectively interpreted the OSH Act and the FLSA, as permitting a joint-employer test that holds both user and supplier firms responsible for legal violations where temporary staffing arrangements are used. $^{40}$ Massachusetts ${ }^{41}$ and Illinois ${ }^{42}$ have also taken the lead in using joint-employment under state laws to hold temporary staffing agencies and user clients liable for violations of temps workplace rights. Yet, under the Board's current variant of the joint-employer test, the economic realities of co-determination of terms and conditions of employment in the temporary staffing agency are all but invisible.

\footnotetext{
${ }^{38}$ Protecting the Safety and Health of Temporary Workers, OSHA, April 29, 2013, https://www.osha.gov/pls/oshaweb /owadisp.show_document? p_table= INTERPRETATIONS\&p_id=28613; see also Updated OIS Coding Instructions Regarding Temporary Workers, OSHA, September 5, 2013.

${ }^{39} \underline{\mathrm{Id}}$.

${ }^{40}$ See infra, n. 35 \& 36 (OSHA); Ruckleshaus, et al., Who's the Boss?, at 33-35 (FLSA); see also Zheng v Liberty Apparel Co, 355 F.3d 61 (2d Cir. 2003)(finding joint employment under FLSA for jobber and primary contractor in garment industry) 617 F3d 182 (2d Cir 2010)(affirming jury verdict for plaintiffs), cert. denied 131 S. Ct. 2879 (2011).

41 See Temporary Worker Right to Know Act, Mass. Gen. Laws ch. 149, § 159C.

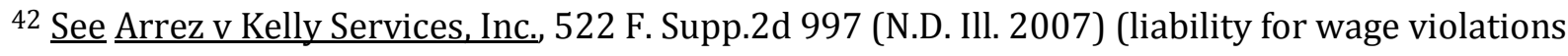
under Illinois Day and Temporary Labor Services Act, 820 ILCS § 175)
} 


\section{TEMPORARY STAFFING ARRANGEMENTS TYPICALLY CREATE TERMS AND CONDITIONS OF EMPLOYMENT THAT ARE CO-DETERMINED BY SUPPLIERS AND USER BUSINESS ENTITIES.}

The Board's joint-employer test is designed to determine whether a putative jointemployer "possesses sufficient control over the work of the employees to qualify as a 'joint employer' with [the actual employer]." NLRB v. Browning-Ferris Industries of Pa., Inc., 691 F.2d at 1123 quoting Boire v. Greyhound Corp., 376 U.S. at 481. Joint-employment requires that "one employer, while contracting in good faith with an otherwise independent company, has retained for itself sufficient control of the terms and conditions of employment of the employees who are employed by the other employer." BrowningFerris, 691 F.2d at 1123. Absolute control over the employees of another employer is not required to establish joint employment. Rather, the test "recognizes that the business entities involved are in fact separate but that they share or co-determine those matters governing the essential terms and conditions of employment. Id. (emphasis in original) citing Cr. Adams Trucking, Inc., 262 NLRB No. 67 (1982); Ref-Chem Co. v. NLRB, 418 F.2d 127, 129 (5 $5^{\text {th }}$ Cir. 1969); NLRB v. Greyhound Corp. 368 F.2d 778, 780 (5th Cir. 1966). Under this longstanding test an examination of temporary staffing arrangements typically presents substantial evidence establishing that the agency supplier and its user client are joint employers of the temporary workforce whose terms and conditions of employment they mutually codetermine. See, e.g. Greyhound Corp. and Floors, Inc., 153 NLRB 1488 (1965), aff'd. 368 F.2d 778 (3rd Cir. 1966).

Amici urges the Board to adopt this variant of the joint-employer test, which was "traditional" and the norm until 1980, when, without expressing intent to overrule Greyhound Corp. and scores of Board rulings applying the same test, a more rigid and 
narrower conception of joint-employment gained sway in Board proceedings. $\underline{\text { See }}$ Amicus Brief of the General Counsel, in M.B. Sturgis/Jeffboat, 331 NLRB 1298 (2000). Prior to the Board's undue reliance on the crabbed application of the joint-employer test in Laerco and $\underline{\text { TLI}}$, it relied on precedent that applied the joint-employer test using a more robust and salient array of factors that better fulfilled the responsibility entrusted to the Board, i.e., to "adapt the Act to changing patterns of industrial life." NLRB v. Weingarten, 420 U.S. 251, 266 (1975).

This regressive unraveling of the joint-employment test is detailed in the General Counsel's Amicus brief submitted in M.B. Sturgis/Jeffboat and amici urges the Board to reconsider and adopt the General Counsel's position on determining joint-employer status. Under this approach, the factors to be examined included, first and foremost, the contractual agreement between the putative joint-employers and, in that light an assessment of whether the agreement and its actual implementation in the workplace revealed shared or codetermined conditions of employment for the relevant group of employees. See Greyhound Corp. and Floors, Inc., 153 NLRB 1488 (1965), aff'd. 368 F.2d 778 ( $3^{\text {rd }}$ Cir. 1966); see also Amicus Brief of the General Counsel, M.B. Sturgis/Jeffboat, 331 NLRB 1298 (and cases cited therein). The practical import of the Board reviving its Board original, better-reasoned explication of the joint-employer standard is made clear when examining the basic structure of temporary staffing arrangements and how it typically gives rise to a joint-employer status for the user and supplier firms. 


\section{APPLICATION OF THE JOINT-EMPLOYER STANDARD TO BARGAINING UNIT DETERMINATIONS INVOLVING THE TEMPORARY STAFFING INDUSTRY REQUIRES THE BOARD TO BE COGNIZANT OF THE DISTINCT FEATURES OF LABOR-ONLY CONTRACTING}

Unlike most businesses engaged in subcontracting, temp agencies neither own or lease capital equipment or technology utilized by its temporary employees to manufacture a product or to provide a unique service for its user client firms. Nor do staffing firms own or lease a physical plant for their workforce. Indeed, a temp's employment relationship and productive work begins and ends on the user employer's premises where all of the productive capital equipment is under the sole control of the user employer. ${ }^{43}$ Thus, temporary staffing agencies are subcontractors that derive their income and profit solely from supplying labor to clients on a "cost-plus" basis, see Greyhound Corp., 153 NLRB at 1494, i.e., at a marked-up hourly billing rate that results in considerable profit after payment of wages paid to their temporary workforce, and overhead, (e.g., taxes, mandatory insurance coverage, office administrative fees). ${ }^{44}$

The realities of codetermination and sharing of responsibility for the temp workers' terms and conditions of employment are recognized by sociologists, human resource specialists and routinely described in temp industry promotional materials and position

\footnotetext{
43 See Gretchen Purser, 'Still Doin' Time': Clamoring for Work in the Day Labor Industry 15 Working USA: The Journal of Labor \& Society 397, 402-3, 410-11 (2012). Temp agency workers are not "employed" until they begin work at the client firm's premises, and are only paid for time clocked in while there. Agreements given to temp workers to sign by "day labor" agencies state that they are "pre-terminated," i.e., deemed to have quit when they leave their assignment at the client' firm's premises each day.

44 George Gonos, Fee Splitting Revisited: Concealing Surplus Value in the Temporary Employment Relationship, 29 Politics \& Society 589 (2001) Notably, in this case, the negotiated a mark-up of the worker's wages set forth in the LBS/BFI agreement is 45.5percent, i.e., LBS temp employees are paid $\$ 8.75$ per hour and LBS charges BFI $\$ 12.38$ per hour for that temp worker's services (the bill rate). Jt. Ex. 1, Ex. A, Rate Schedule.
} 
papers. Sociologists describe the user and supplier of temporary labor as exercising "dual control" 45 where both the temp agency and the client firm maintain ongoing ties to the workforce over the course of the entire assignment. ${ }^{46}$ As one study of temp agencies and client firms concludes, "In triadic employment relationships the function of a traditional employer is shared between the customer firm and an intermediary firm." 47

Aquent, a major temporary staffing firm, describes the user/supplier division of labor in similar terms. Aquent assigns the following employer responsibilities to the staffing company: payment of wages; withholding of payroll taxes; provision of workers compensation, benefits and pension plans ("if applicable"); ensures civil rights compliance; has the right to hire and fire; hears and acts on complaints from temps about working conditions and reports to user firm about working conditions of the employee. ${ }^{48}$ User clients are assigned all other employer responsibilities: supervision and direction of dayto-day work; control of working conditions at the work site; responsibility for ensuring a

${ }^{45}$ Heidi Gottfried, Mechanisms of Control in the Temporary Help Service Industry, 6 Sociological Forum 699 (1991); Heidi Gottfried, Learning the Score: The Duality of Control and Everyday Resistance in the Temporary-Help Service Industry J.M. Jermier, et al., eds., Resistance and Power in Organizations, 102-127 (Routledge 1994).

${ }^{46}$ George Gonos, The Contest Over 'Employer' Status in the Postwar United States: The Case of Temporary Help Firms, 31 Law \& Society Review 81 (1997); Arne Kalleberg, Nonstandard Employment Relations: Part-time, Temporary and Contract Work, 26 Annual Review of Sociology 341 (2000); see also Torstein Nesheim and Ruth Rørvik. Exploring Dilemmas in the Relation Between Temporary Help Agencies and Customer Firms, 42 Personnel Review 67, 68 (2013) ("In triadic employment relationships, the function of a traditional employer is shared between the customer firm and an intermediary firm").

${ }^{47}$ Nesheim and Rørvik. Exploring Dilemmas in the Relation Between Temporary Help Agencies and Customer Firms, 42 Personnel Review at 68.

${ }^{48}$ Managing Co-Employment Risk When Using a Staffing Agency (February 07, 2009), www.aquent.com/blog/managing-co-employment-risk-when-using-a-staffing-agency Last viewed June 17, 2014; previously viewed by author in 2001) as cited in Edward A. Lenz and Dawn R. Greco, Co-Employment: Employer Liability Issues in Third-Party Staffing Arrangements, 17 (American Staffing Association 4th Ed. 2007). 
safe work site including civil rights compliance, and determining the length of the temp workers' assignments. ${ }^{49}$ Kelly Services, another temp industry giant, explicitly explains the shared responsibilities of supplier and user this way:

Kelly pays the employees, pays all payroll taxes, provides workers' compensation coverage, has the ultimate right to hire and fire, hears and acts upon complaints about working conditions, etc. Customers, on the other hand, supervise the employees' work, provide the worksite a tools and equipment, control working conditions at the worksite, and determine the work hours and length of assignment. ${ }^{50}$

This classic description of the division of employer responsibilities as shared by the temporary agency supplier and the user business reflect the economic realities of the arrangement since the founding of the temporary help industry in the late 1940s, including the normal asymmetry of responsibilities that cedes to the user firm primary control over the labor process implemented at the user firm's premises. Edward A. Lenz, Senior Counsel for the American Staffing Association, provides the staffing industry's authoritative description of this arrangement, coining the term "co-employment" to describe the dual or joint control over working conditions exercised by temp agencies and their client firms. ${ }^{51}$ He defines co-employment as "a commercial relationship between two or more businesses in which each has actual or potential legal rights and obligations as an employer with respect to the same employee or group of employees"52 As Lenz states, "Staffing firms and their customers [client firms] often have enough contacts with the assigned employees that

\footnotetext{
${ }^{49} \underline{\mathrm{Id}}$.

${ }^{50}$ A Manager's Guide to Understanding Co-Employment, Kelly Services (1995) (on file with authors)

51 Edward A. Lenz, Co-Employment: Employer Liability Issues in Staffing Services Arrangements (American Staffing Association, $5^{\text {th }}$ Ed. 2003).

52 Id. at 19.
} 
each will be viewed as an employer [... ] Customers [client firms] generally supervise and direct the employees' day-to-day work, control working conditions at the worksite, and determine the length of the assignment." 53 Lenz explains that "co-employment is an inherent aspect of the relationship between the staffing firm and its customers." ${ }^{54}$ As discussed below, Lenz's view is confirmed by staffing industry practices and the express terms of temporary staffing industry service agreements with their user client businesses.

A. $\quad$ Joint-Employment Typically Arises Where Large Concentrations of LongTerm Agency Workers Routinely Carry Out a User Firm's Core Business Functions in a Single Location

The mainstreaming and integration of permatemping into all manner of businesses has altered the labor market role of the temporary staffing industry. To be sure, temps continue to fulfill their original customary function, to cover for absent employees, or serve as short-term, purely supplemental staff during peak periods of demand. ${ }^{55}$ However, notwithstanding the variations in temporary work arrangements, ${ }^{56}$ the staffing industry is no longer reliant on the "reactive" use of temps as short-term replacement personnel. 57 Rather, staffing firms are increasingly retained to provide a "systematic" use of temps, in which entire job clusters, industrial departments and even entire production facilities are

53 Id. at 21.

${ }^{54} \underline{\text { Id. }}$

55 Erin Hatton, The Temp Economy: From Kelly Girls to Permatemps in Postwar America, 75-79 (2011).

${ }^{56}$ See Robert E. Parker, Flesh Peddlers and Warm Bodies: The Temporary Help Industry and its Workers, 40-55 (1994)

${ }^{57}$ Janet Druker and Celia Stanworth, Partnerships and the Private Recruitment Industry, 11 Human Resource Mgt. J. 73 (2001); see Parker, Flesh Peddlers and Warm Bodies at 49 (the acceptance of permatemping and groundwork for its rapid expansion occurred in the high-tech industries during late 1980's and early 1990s). . 
staffed with agency workers indefinitely. ${ }^{58}$ In these situations, temporary agencies are even more prone to "share, or codetermine, those matters governing essential terms and conditions of employment" at the client firm's. See Greyhound Corp., 153 NLRB at 1495 .

The BFI/LBS business relationship typifies the widespread permatemping, throughout today's labor markets. ${ }^{59}$ While many firms continued to hire temps using short-term, lower-volume labor-only agreements, the larger globalized staffing giants began to forge "closer partnership arrangements" and negotiate "preferred supplier contracts" with large clients. ${ }^{60}$ As these high-volume, long-term staffing partnerships spread, the standardized, simple contract forms used to arrange temporary hires to 'fill-in' for vacationing employees, to accommodate absenteeism or seasonal shifts in production ${ }^{61}$ were replaced by elaborated, negotiated "framework agreements" that detail codetermined terms and conditions of employment and the mutual, shared obligations of the supplier agency and user firm. ${ }^{62}$

$58 \underline{\text { See Vidal and Tigges, Temporary Employment and Strategic Staffing in the Manufacturing Sector, }}$
48 Industrial Relations at $55-72$.).

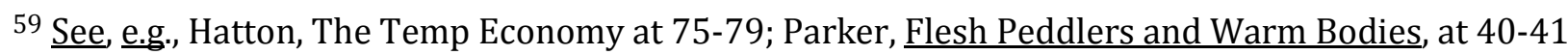
(identifying and predicting the proliferation of permtemping or "planned staffing").

60 Druker and Stanworth, Partnerships, Human Resource Mgt. J. at pincite; see James Peck and Nik Theodore, The Business of Contingent Work, 12 Work, Employment \& Society 655, 656 (1998) (identifying "corporate partnering" and "mutual interdependencies" of larger temporary staffing firms and user clients).

61 The simplest form of contractual agreement is exemplified in Manpower Inc. of Shelby Cty., 164 NLRB No. 137 (1967) where joint employment of truck drivers rested an oral agreement setting the key terms and conditions of employment.

62 Nesheim, et al., Exploring Dilemmas in the Relation Between Temporary Help Agencies and Customer Firms, 42 Personnel Rev. at 68 \& 73, n. 72. 
In high-volume permatemping arrangements, temp agencies often offer to provide on-site staffing agency personnel to participate in supervising the user client's temporary workforce. This so-called, 'vendor-on-premises' model (VOP), utilized by LBS, originated with staffing agency representatives visiting client firms to ensure contract renewals. Onsite agency supervision does not always accompany high-volume temp agency agreements. Moreover, when it does, the presence of temp agency supervisory personnel does not fundamentally alter the economic realities of temping arrangements, in which the user and supplier firms codetermine and share the terms and conditions employment.

The high-volume, concentrated deployment of temps that is evidenced in this case requires temporary staffing firms to be involved with and routinely factored into their user client's management planning and deeply integrated into the day-to-day performance of the essential functions of the client's business product or service. ${ }^{63}$ Indeed, 240 LBS temps are assigned to the BFI recycling facility for an indefinite term as the sole workforce staffing BFI's seven recycling assembly lines. Regional Director's Decision and Direction of an Election, 4 (Aug. 16, 2013). But, contrary to the Regional Director's conclusion, this type of structural integration, as evidenced in the record, establishes that BFI and LBS share and codetermine the terms and conditions of the temporary worker unit in this case.

B. The BFI/LBS Temporary Labor Services Agreement As Written and Implemented Establishes Co-Determined and Shared Terms and Conditions of Employment

The Regional Director's conclusion that BFI is not a joint-employer should be reversed as it accords far too little factual weight and legal import to the LBS/BFI

63 Jackie Krass Rogers, Temps: The Many Faces of the Changing Workplace, 165 (ILR Press 2000) (triangulated temp work creates "two bosses, one of whom is paid to provide a service to the other). 
Temporary Labor Services Agreement. Jt. Ex. 1. In the seminal joint-employment case, Greyhound Corp. and Floors, Inc., following the Court's directive in Boire v. Greyhound, 376 U.S. at 481, (i.e., to examine whether the putative joint-employer exercised "sufficient control over the work of the employees"), the Board focused on whether the service agreements entered into by Greyhound and its subcontractor, Floors, exhibited the requisite level of control to establish joint-employer status for Greyhound, the user firm. 153 NLRB at 1492. The Regional Director's ruling in this case did not follow the test in Greyhound Corp. Instead, the decision treated the BFI/LBS Staffing Agreement superficially and ignored material provisions in it that allocate to BFI the highest and most determinative levels of control over the terms and conditions of employment.

Of particular importance to the unit determination of BFI/LBS temp workers (and any unit determination involving temporary staffing agencies), is the emphasis the Board has placed on the express terms in staffing agreements that provide for the "services to be rendered [by the supplier] and proper result achieved 'by discretion of contractor, contractor's supervisory staff and in agreement with the [contractor's] Management."' Greyhound Corp., 153 NLRB at 1492 (quoting parties' service agreement). A strikingly similar clause opens the BFI/LBS Agreement:64 "Agency (LBS) [ ... ] acknowledges that Client (BFI) conducts it business directly [...] and that the Personnel [the] Agency furnishes under this Agreement will be furnished to Client [ . . . ] as Client directs." Jt. Ex. 1 (emphasis added). This clause establishes the duality of control exercised by BFI and LBS as it explicitly reserves to the user employer the right "to closely survey and direct the

\footnotetext{
64 Similar clauses are routinely included in temporary staffing agreements. See $\underline{\text { Carillo v. Schneider }}$ Logistics, Inc., No. 11-08557 (C.D. Cal. 2011) Staffing Agreement (on file with authors).
} 
actual means and methods utilized by its subcontractor to affect substantially the actual work processes of these employees." Greyhound Corp., 153 NLRB at 1492; see Sun-Maid Growers and IBEW Local 100, 239 NLRB 346, 348 (1978). (finding joint employment when employees' duties integral to user's production process and agreement did not vest in supplier independent control of employees that is inconsistent with user exercising substantial control over manner and means by which joint employees performed services).

The Regional Director's decision either ignores or gives short shrift this and to other terms enumerated in the BFI/LBS agreement that cede critical indicia of control over the temporary workforce's terms and conditions of employment to BFI supervisors and management. These include: BFI setting a ceiling for the temp workers wage rates, Jt. Ex. 1, par. 3; BFI's responsibility for skills training and/or safety training of employees when the "position requires [... ] knowledge or ability that is particular to Client's operation," Jt. Jt. Ex. 1, par. 4 \& 5; Client's right to set "standard selection procedures and tests" used to hire temps, Jt. Ex. 1, par 4; Client's "right to reject or discontinue use of "any temporary employees "for any or no reason" including to reject workers previously directly employed by BFI or those not "free from the effects of drugs or alcohol"; Jt. Ex. 1., par. 4 \& 7.65

Given the structure of temporary staffing agreements and the manner in which they are implemented, the Regional Director's refrain - that supervision was performed "solely" by the staffing agency, LBS - lacks factual foundation. This unduly reductive approach,

65 The temporary staffing industry's standard practice is to cede to user employers the right to terminate temps. Consider, for example, the stated policy of the Microsoft Contingent Staffing Group: "As a reminder, you do not have a contract with that temporary employee: you are free to end the assignment [...]." Microsoft Overhauls Permatemp Compensation, Washington Alliance of Technology Workers/WashTech (Oct 26, 1998), www. washtech.org/roundup/ billrate.html (quoting policy of Microsoft's exclusive temporary labor provider)(on file with authors). 
which drives the Regional Director's flawed reasoning, is problematic when determining joint-employment in temporary staffing scenarios as it ignores the economic realities of temporary staffing arrangements that vest the user employer with primary control of the work processes. Contrary to the legal conclusions the Regional Director draws from the record, the LBS on-site supervisory team does not perform its routine, daily duties independently (i.e. "solely"). Each and every aspect of their supervisory responsibility is carried out pursuant to the terms of the co-determined BFI/LBS Staffing Agreement and in accordance with management policies and supervisory directives provided to LBS supervisors and temps by BFI personnel assigned to manage and supervise its facility.

The primacy of BFI's control over key terms and conditions of the temporary workforce is underscored by the fact that the LBS on-site manager attends BFI's daily management staff meetings. TR: 107; Leadpoint, Ex. 2D. Aside from whatever directives LBS's on-site manager receives at these meetings, TR: 75, BFI holds and exercises sole control over the production lines. TR: 75, 90. BFI's facility supervisor has sole control over the speed of the belt on the recycling lines where LBS temps are assigned. TR: 109. BFI operations manager Paul Keck routinely directs LBS's site manager or shift leads to address problems he identifies. TR: 128 . Notably, right after Keck witnessed two temp workers using alcohol on the job, he exercised the authority that the Staffing Agreement vests in BFI to direct LBS to immediately dismiss these workers. TR: 130; Union Ex. 2. Keck also instructed LBS supervisors to reduce by two the temps assigned to a recycling line. TR: 54, 148 \& Union Ex. 1. Notably, BFI also controls the length of employment at the facility, as the Staffing Agreement requires that LBS temps end their work duties at BFI after six months and re-employment cannot occur for one year. Jt. Ex. 1, par. 4. 
BFI facility supervisors also exercise their authority to responsibly direct the work of the LBS temporary employees through daily orders and directives issued by BFI senior management to LBS supervisors via walkie-talkies (that BFI issues to LBS supervisory staff), TR: $62,104,120$, or in written memos and in face-to-face oral exchanges with supervisors and temp workers. These directives: determine whether LBS temps will work overtime on any given day, TR: 107-108; instruct LBS leads as to the when the emergency stop button may be used, TR: 103; direct temp workers on proper use of tools; resolve issues regarding quality control issues on the recycling lines or in cleaning of work areas, TR: 98,112; establish when and whether to fix breakdowns on the recycling lines, TR: 115, and; resolve quality control or cleaning issues. TR: 112 .

There is no instance in the record where LBS supervisors deviated from the parties Staffing Agreement or that LBS ignored, refused to follow or altered the supervisory directives routinely issued to them by BFI management personnel. In this context, LBS's role as front-line supervisors does not prove that BFI is not involved in day-to-day supervision. Indeed, LBS supervisors are at the bottom of the BFI chain of command, where they carry out the most ministerial levels of supervision that often requires only minimal levels of independent judgment. This pecking order establishes the significance and extent of BFI's control over all aspects of its facility where BFI directives to LBS supervisors (and to LBS temps) is required to effectuate the wholesale integration of the temporary workforce into the user's core business operations.

C. Wages, Hours of Work and Health and Safety Conditions are Co-determined and Shared by BFI and LBS

Joint-employer status should be assigned to BFI because, like LBS it "exert[s] significant control over the same employees" terms and conditions of employment. NLRB v. 
Western Temporary Services, 821 F.2d 1258, 1256 (7th Cir. 1987) (citing Boire v.

Greyhound, 376 U.S. 473 and Browning-Ferris Industries, 691 F.2d 1117, for test of jointemployer status). Notably, Greyhound Corp.'s joint-employer finding also rested on "other provisions" in the parties' agreement that bear directly on what the Board referred to as "the more orthodox terms and conditions of employment," - wages, overtime, scheduling and assignment to job functions - that, if shared or codetermined, can give rise to joint employment. 153 NLRB at 1492-1493. The parties' agreement conferred on Greyhound the right to set the total hours of work and the "precise" time for employment as well as the shift schedules, and authorization of any overtime work. Id. Based on these findings, and because the contract was "cost-plus," Greyhound was found to "share with Floors in a substantial way the power to establish the wages of these employees - a power that goes to the crux of any employment relationship." $\underline{\text { dd. at }} 1494$ (emphasis added).

Here, the record contains analogous facts indicating that BFI and LBS codetermine and share control over the hours and wages of the temporary workforce. BFI sets the shifts for the lines where the temporary workers perform their tasks, TR: 39, and schedules which days specific recycling lines are running, TR: 36 . BFI even controls when the temp workers take their breaks. TR: 220-221. These facts establish that BFI management determines the hours of work, i.e, when the parties' temporary workforce is employed. In other words, BFI - through its "promulgation of work rules and conditions of employment, work assignments, and issuance of operating instructions" - exercises control over terms and conditions of employment that the Board and federal appeals courts have held to be sufficient indicia of control to find joint-employer status. $\underline{\text { See }} \underline{\text { G. Heilman Brewing Co., Inc. v. }}$ NLRB, 879 F.2d 1526, 1531 (7th Cir. 1989) quoting W.W. Grainger v. NLRB, 860 F.2d 244, 
247 (7th Cir. 1978). Plainly, BFI and LBS have divided up supervisory responsibilities to allow both to "exert significant control over the same employees" hours of work. See NLRB v. Western Temporary Services, 821 F.2d 1258, 1256 ( $7^{\text {th }}$ Cir. 1987) (to determine wages paid and fees charged, user employer verifies hours recorded on temp agency time sheets). Wages are also codetermined as evidenced by the fact that both LBS and BFI "exert significant control over the same employees" hourly rate and whether overtime pay is earned. Id. First, BFI solely determines and controls the wage ceiling of the unit employees pursuant to the mutually agreed upon terms of the Staffing Agreement, which requires that LBS pay temp workers less than the wage of BFI employees performing similar work. Jt. Ex. 1, par. 3 (equal or higher wage requires BFI's prior approval). Moreover, the Staffing Agreement expressly sets the wage rates for the unit employees (\$8.75 straight time) $\$ 13.12$ overtime) and the mark-up rate from which LBS's billing rate is calculated (as a multiplier of the hourly wage). Jt. Ex. 1, Ex. A. ${ }^{66}$ By negotiating and signing off on the wage and mark-up rate in the Staffing Agreement, BFI is co-determining wage rates for the temp workers assigned to its facility. ${ }^{67}$ Additionally, both BFI and LBS play a role in making sure

\footnotetext{
66 Sociological research into the actual nature of negotiations between temp agencies and their clients has found that the process "left considerable scope for bargaining" and "often occasioned pointed, protracted, and sometimes heated bargaining." Stephen R. Barley and Gideon Kunda, Gurus, Hired Guns, and Warm Bodies: Itinerant Workers in a Knowledge Economy, 135, 144 (2004). Once established, wage rates and bill rates are locked together in a relatively rigid "costplus" relationship. Temp agencies follow an "implicit rule to maintain or increase margins per transaction, and do[...] so by paying a variable wage to the worker-depending on the bill rate charged to the client. ... A consequence of this is that the risk is pushed onto the workers, whose wages then depend on the specific rates charged to the clients per transaction."
}

67 In some agency-client partnerships, co-determination of pay rates is contractual: "Kelly will work closely with J \& J to implement a pay rate management process that will analyze current pay rates against the market. The goal is to pay contract labor/temporary help at competitive pay rates. Kelly will provide J \& J with reports on a semi-annual basis and work with J \& J management and local branch personnel to meet the targeted objectives. Johnson\& Johnson/Kelly Services Contract Highlights (January 1995) (copy in the possession of the authors). 
that worker's hours are correctly recorded and that BFI is accurately charged for the hours worked by the unit's workforce. Jt. Ex. 1, par. 5; see Western Temporary Services, 821 F.2d at 1256 . As for overtime pay, LBS only assigns overtime duty pursuant to directives it receives from BFI management daily. TR: 107-108.

The Regional Director's failure to address whether BFI and LBS share or codetermine the health and safety conditions of the unit of temporary workers is yet another example of the wooden analysis arising from the Laerco/TSI variant of the jointemployer test. Using this approach, health and safety are treated only as a byproduct of BFI's property rights, ignoring its patent control over health and safety issues arising from its status as the user employer. Decision at 13-14. This approach should be rejected by the Board and replaced by a joint-employer test that is re-infused with factors that consider the economic realities of workplace health and safety where temporary staffing arrangements are in play. These realities of joint-employment are succinctly described by OSHA, which explicitly adopted the view that staffing agencies and their clients are "typically" joint employers when it comes to determining health and safety:

When a staffing agency supplies temporary workers to a business, typically, the staffing agency and the staffing firm client [ ] are joint employers of those workers. Both employers are responsible to some degree for determining the conditions of employment and for complying with the law. ${ }^{68}$

Given that health and safety issues are core workplace conditions and mandatory terms of bargaining, the Board should give substantial consideration to OSHA's conclusion temporary staffing arrangements "typically" give rise to joint employment because "[b]oth

68 Injury and Illness Recordkeeping Requirements, TWI Bulletin No. 1, OSHA 
employers are responsible to some degree for determining the conditions of employment and for complying with the law." 69

\section{WAGES, HOURS AND CONDITIONS OF WORK CANNOT BE EFFECTIVELY BARGAINED WITHOUT HAVING THE SUPPLIER AND USER OF THE TEMPORARY WORKFORCE AT THE BARGAINING TABLE}

The Laerco/TSI variant of the joint-employer test is a barrier to self-organization and collective bargaining. Under this test, the Board offers little by way of meaningful collective bargaining rights to the BFI/LBS temps and the millions of other workers employed in enterprises where temporary staffing arrangements divide the workforce into standard and temporary segments. Unless unit determinations result in the user and supplier employers both being present at the bargaining table, temp workers will not be able to negotiate co-determined terms and conditions of employment that contribute to their second tier status in the labor force.

There is nothing in the statutory text of the NLRA that prevents the Board from adopting a more robust set of factors to determine joint-employer status in a manner that keeps "pace with changing patterns of industrial life." See Weingarten, 420 U.S. at 266. Indeed, the relevant statutory text gives the Board the ability to vary the appropriate unit for collective bargaining purposes to include "the employer unit, craft unit, plant unit, or other unit. 29 U.S.C. \$159(b) (emphasis added). As such, both the user and supplier employers are properly assigned to bargain jointly with a unit including temp workers.

Similarly, the Act's definition of supervisor and employer grants the Board wide latitude in determining whether a user employer is engaged in supervising the temporary workforce to a significant extent, i.e., sufficient to establish the necessary indicia of control

${ }^{69}$ Id. 
for joint-employer status. G. Heilman Brewing Co. 879 F.2d at 1531. The term supervisor has been given broad meaning. NLRB v. Kentucky River Community Care, Inc., 532 U.S. 706 (2001) (supervisory status established when exercising any one of the eleven criteria set forth in 29 U.S.C. § 152(11) ${ }^{70}$ ); Oakwood Healthcare, Inc., 348 NLRB 686, 691-692 (2006)(supervisory status established by authority to take corrective action and assume consequences for failure to do so). In this regard, there is no reason why factors used to determine supervisory control of a temporary workforce should be as narrowly construed as they are in Laerco and TSI, which caused the Regional Director to ignore facts showing that BFI supervisors consistently used their "authority," derived from the Staffing Agreement, when exercising "independent judgment" to either "responsibly direct" the LBS temporary workforce or to "effectively [... recommend" a bevy of directives to the LBS temporary workers. See 29 U.S.C. § 152(11). Nothing in the Act's definition of supervisor or employer, permits the Board to ignore these significant indicia of supervision solely because the directives were issued by top-level BFI supervisors to low-level LBS supervisors, rather than to the temporary employees directly.

The joint-employer test applied in this case also undermines federal labor policy as it obstructs the efficacy of collective bargaining and, thereby, increases the potential for strikes and other forms of industrial strife or unrest in workplaces where temporary staffing arrangements are used. $\underline{\text { See } 29}$ U.S.C. $\$ 151$ (Findings). A host of mandatory subject of bargaining that LBS unit employees might choose to bring to the bargaining table cannot

\footnotetext{
70 The Act defines supervisor to mean "any individual having authority, in the interest of the employer, to hire, transfer, suspend, lay off, recall, promote, discharge, assign, reward, or discipline other employees, or responsibly to direct them, or to adjust their grievances, or effectively to recommend such action, if in connection with the foregoing the exercise of such authority is not of a merely routine or clerical nature, but requires the use of independent judgment."
} 
meaningfully be addressed without involving BFI, the user employer in the bargaining process. Consider just some of the mandatory bargainable subjects: speed of the recycling lines; the hours of work; break scheduling; wage increases to create parity with standard BFI employees performing the same work as temps; adjustment or changes to safety rules promulgated by BFI that are implemented pursuant to the Staffing Agreement, or; a change in the six-month limit on the unit members' employment at BFI facilities. Each of these mandatory subjects of bargaining are either in the sole control of BFI or under the control over terms and conditions of employment codetermined or shared by BFI and LBS. It takes little imagination to foresee the potential for industrial strife when user employers, like $\mathrm{BFI}$, who codetermine the terms and conditions of the temporary workers at their facilities, are legally excluded from bargaining relationships established by the Board.

\section{CONCLUSION}

For all these reasons, the Board should find that BFI is a joint-employer of the temporary workforce at its facility and to order BFI to join LBS in the process of collective bargaining should the unit workers vote to join Teamsters Local 350.

Respectfully Submitted,

LABOR RELATIONS AND RESEARCH CENTER University of Massachusetts, Amherst, MA 01003 www.umass.edu/lrrc/ 
June 26,2014

By,

s/ Harris Freeman

Harris Freeman, BBO \# 264353

Professor, Western New England University

School of Law

1215 Wilbraham Rd, Springfield, MA 01119

413-221-3746

Harris.Freeman@law.wne.edu

s/George Gonos

George Gonos, Ph.D.

Professor, Department of Sociology

State University of New York

Potsdam, NY 13676/ 786-803-8360

gonosgc@potsdam.edu 


\section{CERTIFICATE OF SERVICE}

By Electronic Service: This brief was sent to the attorneys for the parties to this proceeding at the electronic notification addresses list below. I did not receive, within a reasonable time after the transmission, any electronic message or other indication that the email transmission was unsuccessful.

Susan K. Garea

Beeson, Tayer \& Bodine, APC

483 Ninth St., $2^{\text {nd }}$ FL

Oakland, CA 94607-4051

510-625-9700

Fax: 510-625-8275

Email: SGarea@beesontayer.com

Michael G. Pedhirney

Littler Mendelson, P.C.

650 California St., $20^{\text {th }} \mathrm{FL}$

San Francisco, CA 94108

415-677-3117

Fax: 415-743-6596

Email: mpedhirney@littler.com

Elizabeth M. Townsend

Ogletree, Deakins, Nash, Smoak, Stewart, PC

Esplanade Center Ill, Suite 800

Phoenix, AZ 85016

602-778-3700

Fax: 602-778-3750

Email: Elizabeth.townsend@ogletreedeakins.com 